\title{
Probing the diversity of chloromethane-degrading bacteria by comparative genomics and isotopic fractionation
}

\author{
Thierry Nadalig ${ }^{1}{ }^{*}$, Markus Greule $^{2}$, Françoise Bringel ${ }^{1}$, Frank Keppler ${ }^{2}$ and Stéphane Vuilleumier ${ }^{1}$ \\ 'Université de Strasbourg, Equipe Adaptations et Interactions Microbiennes dans I'Environnement, Unitès Mixtes de Recherche 7156 Centre National de la \\ Recherche Scientifique, Génétique Moléculaire, Génomique, Microbiologie, Strasbourg, France \\ 2 Institute of Earth Sciences, Ruprecht Karls University Heidelberg, Heidelberg, Germany
}

\section{Edited by:}

Colin Murrell, University of East

Anglia, UK

Reviewed by:

Steffen Kolb, University of Bayreuth, Germany

Ronald Oremland, United States Geological Survey, USA

Jeremy Semrau, University of

Michigan, USA

\section{*Correspondence:}

Thierry Nadalig, Université de Strasbourg, Equipe Adaptations et Interactions Microbiennes dans I'Environnement, Unités Mixtes de Recherche 7156 Centre National de la Recherche Scientifique, Génétique Moléculaire, Génomique Microbiologie, 28 rue Goethe, 67083 Strasbourg Cedex, France e-mail:nadalig@unistra.fr
Chloromethane $\left(\mathrm{CH}_{3} \mathrm{Cl}\right)$ is produced on earth by a variety of abiotic and biological processes. It is the most important halogenated trace gas in the atmosphere, where it contributes to ozone destruction. Current estimates of the global $\mathrm{CH}_{3} \mathrm{Cl}$ budget are uncertain and suggest that microorganisms might play a more important role in degrading atmospheric $\mathrm{CH}_{3} \mathrm{Cl}$ than previously thought. Its degradation by bacteria has been demonstrated in marine, terrestrial, and phyllospheric environments. Improving our knowledge of these degradation processes and their magnitude is thus highly relevant for a better understanding of the global budget of $\mathrm{CH}_{3} \mathrm{Cl}$. The $\mathrm{cmu}$ pathway, for chloromethane utilisation, is the only microbial pathway for $\mathrm{CH}_{3} \mathrm{Cl}$ degradation elucidated so far, and was characterized in detail in aerobic methylotrophic Alphaproteobacteria. Here, we reveal the potential of using a two-pronged approach involving a combination of comparative genomics and isotopic fractionation during $\mathrm{CH}_{3} \mathrm{Cl}$ degradation to newly address the question of the diversity of chloromethane-degrading bacteria in the environment. Analysis of available bacterial genome sequences reveals that several bacteria not yet known to degrade $\mathrm{CH}_{3} \mathrm{Cl}$ contain part or all of the complement of $\mathrm{cmu}$ genes required for $\mathrm{CH}_{3} \mathrm{Cl}$ degradation. These organisms, unlike bacteria shown to grow with $\mathrm{CH}_{3} \mathrm{Cl}$ using the $\mathrm{cmu}$ pathway, are obligate anaerobes. On the other hand, analysis of the complete genome of the chloromethanedegrading bacterium Leisingera methylohalidivorans MB2 showed that this bacterium does not contain $\mathrm{cmu}$ genes. Isotope fractionation experiments with $L$. methylohalidivorans MB2 suggest that the unknown pathway used by this bacterium for growth with $\mathrm{CH}_{3} \mathrm{Cl}$ can be differentiated from the cmu pathway. This result opens the prospect that contributions from bacteria with the $\mathrm{cmu}$ and Leisingera-type pathways to the atmospheric $\mathrm{CH}_{3} \mathrm{Cl}$ budget may be teased apart in the future.

Keywords: bacteria, chloromethane, comparative genomics, isotope fractionation, diversity

\section{INTRODUCTION}

Halocarbons such as chloromethane $\left(\mathrm{CH}_{3} \mathrm{Cl}\right)$ and bromomethane are known for their ozone depletion potential (Harper, 2000). $\mathrm{CH}_{3} \mathrm{Cl}$, the most abundant volatile halocarbon in the atmosphere $(\sim 600 \mathrm{ppt})$, is responsible for approximately $15 \%$ of halogen-dependent ozone destruction in the stratosphere (Harper, 2000; Montzka and Reimann, 2011). The largest sources of $\mathrm{CH}_{3} \mathrm{Cl}$ emissions to the atmosphere include terrestrial vegetation (Hamilton etal., 2003; Yoshida et al., 2004; Keppler et al., 2005) and in particular the phyllosphere (i.e., aboveground parts of vegetation, Saito and Yokouchi, 2008), biomass burning, and the oceans (Montzka and Reimann, 2011). Conversely, the dominant sink for $\mathrm{CH}_{3} \mathrm{Cl}$ is via reaction with hydroxyl radicals in the troposphere and represents $84 \%$ of the total, estimated at $4.1 \mathrm{Tg} \mathrm{Cl} \mathrm{yr}^{-1}$ (Yoshida etal., 2004). However, certain methylotrophic bacteria capable of using $\mathrm{CH}_{3} \mathrm{Cl}$ as their sole source of carbon and energy for growth may also participate in this process, but the magnitude of their contribution remains to be characterized. Chloromethane-degrading bacteria are quite widespread, with representatives affiliated to the genera
Aminobacter, Hyphomicrobium, Leisingera, Methylobacterium, Roseovarius (Alpha-Proteobacteria), Pseudomonas (GammaProteobacteria) and Acetobacterium (Actinobacteria), isolated from diverse environments such as soils (Doronina et al., 1996; Miller etal., 1997; Coulter etal., 1999; McAnulla et al., 2001), activated sludge (Hartmans et al., 1986; Traunecker et al., 1991; Freedman et al., 2004), freshwaters (McAnulla et al., 2001), and seawater (Schäfer et al., 2005).

The only pathway for $\mathrm{CH}_{3} \mathrm{Cl}$ degradation known so far is corrinoid- and tetrahydrofolate-dependent, and was characterized in detail for the aerobic facultative methylotrophic strain Methylobacterium extorquens CM4 (Vannelli et al., 1999). This pathway, termed $с т и$ (abbreviation for chloromethane utilization), involves a set of genes that were subsequently detected in several other chloromethane-degrading strains (reviewed in Schäfer et al., 2007; also see Nadalig et al., 2011). The first step of the сти pathway involves the methyltransferase/corrinoid-binding CmuA protein, which transfers the $\mathrm{CH}_{3} \mathrm{Cl}$ methyl group to a corrinoid cofactor, and $\mathrm{CmuB}$, another methyltransferase which catalyzes the transfer of the methyl group from the methylated 
corrinoid to tetrahydrofolate $\left(\mathrm{H}_{4} \mathrm{~F}\right)$. Methyl- $\mathrm{H}_{4} \mathrm{~F}$ is then oxidized to methylene- $\mathrm{H}_{4} \mathrm{~F}$ and further to $\mathrm{CO}_{2}$ via formate to conserve energy, or exploited for biomass production. However, other yet to be characterized metabolic pathways may be involved in the degradation of $\mathrm{CH}_{3} \mathrm{Cl}$ in the environment. For example, Leisingera methylohalidivorans $\mathrm{MB} 2$ grows with methyl halides but was reported not to contain close homologs of $\mathrm{cmu}$ genes (Schäfer et al., 2007).

Evidence for a given metabolic pathway may be obtained through the use of stable isotope techniques, and this has been used to distinguish different sources and sinks for $\mathrm{CH}_{3} \mathrm{Cl}$ (Harper et al., 2001, 2003; Czapiewski et al., 2002; Keppler et al., 2004, 2005; Saito and Yokouchi, 2008; Greule et al., 2012; Redeker and Kalin, 2012). Degradation of $\mathrm{CH}_{3} \mathrm{Cl}$ by cell suspensions of strains with the cmu pathway is also associated with specific carbon fractionation (Miller etal., 2001) but also with hydrogen isotope fractionation (Nadalig et al., 2013). Thus, isotopic approaches combined with genomic approaches may prove decisive in constraining the bacterial contribution to the global $\mathrm{CH}_{3} \mathrm{Cl}$ budget.

In the present study, we review available bacterial genome sequences for the presence of $\mathrm{cmu}$ genes, thereby uncovering several bacteria that have not been described to degrade $\mathrm{CH}_{3} \mathrm{Cl}$. In parallel and as a proof of concept for the potential of isotope methods to characterize yet unknown pathways for $\mathrm{CH}_{3} \mathrm{Cl}$ degradation, we determined hydrogen and carbon isotopic fractionation patterns of $\mathrm{CH}_{3} \mathrm{Cl}$ during growth of the chloromethane-degrading strain L. methylohalidivorans MB2 lacking cmu genes, as compared to that observed for cmu pathway strains M. extorquens CM4 and Hyphomicrobium sp. MC1.

\section{MATERIALS AND METHODS BIOINFORMATIC ANALYSIS}

Comparative genome analysis was performed with the software tools available on the Microscope platform at Genoscope (Vallenet et al., 2009), using the assembled sequences of M. extorquens CM4 (GenBank accession numbers CP001298, CP001299, CP001300), Hyphomicrobium sp. MC1 (FQ859181), Desulfomonile tiedjei (CP003360, CP003361), Thermosediminibacter oceani (CP002131), Thermincola potens (CP002028), and L. methylohalidivorans MB2 (CP006773, CP006774, СР006775), and the draft sequences for Desulfotomaculum alcoholivorax (GenBank AUMW00000000; 66 contigs), Desulfurispora thermophila (GenBank AQWN00000000; 19 contigs; Table 1).

\section{BACTERIAL STRAINS AND GROWTH CONDITIONS}

Strains M. extorquens CM4 and Hyphomicrobium sp. MC1 were laboratory stocks and cultivated in a mineral medium for methylotrophic bacteria (M3; Roselli et al., 2013) containing $\left(\mathrm{L}^{-1}\right.$ of distilled water) $\mathrm{KH}_{2} \mathrm{PO}_{4}(6.8 \mathrm{~g}),\left(\mathrm{NH}_{4}\right)_{2} \mathrm{SO}_{4}(0.2 \mathrm{~g}), \mathrm{NaOH}(5 \mathrm{M})$ $(5.85 \mathrm{~mL})$, yielding a final $\mathrm{pH}$ of 7.2 . After autoclaving, $1 \mathrm{~mL}$ $\mathrm{L}^{-1}$ medium each of calcium nitrate solution $\left(25 \mathrm{~g} \mathrm{~L}^{-1}\right)$ and of trace elements solution containing $\left(\mathrm{mg} \mathrm{L}^{-1}\right) \mathrm{FeSO}_{4} 7 \mathrm{H}_{2} \mathrm{O}(100)$, $\mathrm{MnSO}_{4} \mathrm{H}_{2} \mathrm{O}$ (100), $\mathrm{ZnSO}_{4}$ (29.5), $\mathrm{Co}\left(\mathrm{NO}_{3}\right)_{2} 6 \mathrm{H}_{2} \mathrm{O}$ (25), $\mathrm{CuCl}_{2}$ $\mathrm{H}_{2} \mathrm{O}(25), \mathrm{Na}_{2} \mathrm{MoO}_{4} 2 \mathrm{H}_{2} \mathrm{O}(25), \mathrm{NH}_{4} \mathrm{VO}_{3}(14.4), \mathrm{NiSO}_{4} 6 \mathrm{H}_{2} \mathrm{O}$ (10), $\mathrm{H}_{3} \mathrm{BO}_{3}$ (10), and $0.5 \mathrm{~mL} \mathrm{~L}{ }^{-1}$ of $\mathrm{H}_{2} \mathrm{SO}_{4}$ (95\%) were added. Strain L. methylohalidivorans MB2 (DSM 14336) was obtained from DSMZ (Braunschweig, Germany) and cultivated in a mineral medium (MAMS) containing $\left(\mathrm{L}^{-1}\right.$ of distilled water) $\mathrm{NaCl}(16 \mathrm{~g})$, $\left(\mathrm{NH}_{4}\right)_{2} \mathrm{SO}_{4}(1 \mathrm{~g}), \mathrm{MgSO}_{4} \quad 7 \mathrm{H}_{2} \mathrm{O}(1 \mathrm{~g}), \mathrm{CaCl}_{2} 2 \mathrm{H}_{2} \mathrm{O}(0.2 \mathrm{~g})$, $\mathrm{KH}_{2} \mathrm{PO}_{4}(0.36 \mathrm{~g})$, and $\mathrm{K}_{2} \mathrm{HPO}_{4}(2.34 \mathrm{~g})$ as described (Schaefer et al., 2002). After autoclaving, $1 \mathrm{~mL} \mathrm{~L}^{-1}$ medium of trace elements solution was added. Strains CM4, MC1, and MB2 were grown with $\mathrm{CH}_{3} \mathrm{Cl}$ gas $[10 \mathrm{~mL}$ (Fluka), effectively yielding approximately $10 \mathrm{mM}$ final concentration], in $300 \mathrm{~mL}$ Erlenmeyer vials fitted with sealed mininert valve caps (Sigma) and containing $50 \mathrm{~mL}$ of medium. Cultures were incubated at $30^{\circ} \mathrm{C}$ on a rotary shaker $(100 \mathrm{rpm})$. Abiotic controls (no bacteria added) were prepared and incubated in the same way. Growth was followed by absorbance measurement at $600 \mathrm{~nm}$.

The headspace of cultures was sampled regularly $(0.1 \mathrm{~mL})$ for determination of $\mathrm{CH}_{3} \mathrm{Cl}$ concentration by gas chromatography, and $1 \mathrm{~mL}$ headspace samples were also taken at each point and conserved in $12 \mathrm{ml}$ Exetainers ${ }^{\circledR}$ (Labco Limited, Lampeter, UK) for subsequent isotopic measurements. Concentration of chloride was measured in supernatants of cultures using the spectrophotometric method of Jörg and Bertau (2004), except for $L$. methylohalidivorans MB2 because of the high chloride content of MAMS medium.

\section{ANALYSIS OF CONCENTRATIONS AND STABLE ISOTOPE VALUES OF CHLOROMETHANE}

Concentration and stable carbon and hydrogen isotope values for $\mathrm{CH}_{3} \mathrm{Cl}$ were performed by gas chromatography coupled with flame ionization detector (GC-FID) and isotope ratio mass spectrometry (IRMS), respectively, as described previously (Nadalig et al., 2013), except that helium flow entering the gas chromatograph in isotopic analysis was increased to $1.8 \mathrm{ml} \mathrm{min}^{-1}$.

The conventional "delta" notation, which expresses the isotopic composition of a material relative to that of a standard on a per mil (\%o) deviation basis, was used. Values of $\delta^{2} \mathrm{H}(\%)$ are relative to that for V-SMOW (Vienna Standard Mean Ocean Water), and values of $\delta^{13} \mathrm{C}(\%)$ are relative to that for V-PDB (Vienna Pee Dee Belemnite). Carbon and hydrogen isotope fractionations associated with $\mathrm{CH}_{3} \mathrm{Cl}$ degradation by L. methylohalidivorans $\mathrm{MB} 2$, M. extorquens CM4 and $H$. sp. MC1 were determined from the slopes $\left(b_{\mathrm{C}}\right.$ and $\left.b_{\mathrm{H}}\right)$ of the linear regression of isotope variation $\left({ }^{13} \mathrm{C}\right.$ and $\left.\delta^{2} \mathrm{H}\right)$ of $\mathrm{CH}_{3} \mathrm{Cl}$ on the logarithm of the remaining $\mathrm{CH}_{3} \mathrm{Cl}$ concentration $(\ln \mathrm{f})$ :

$$
b_{\mathrm{C}}=\delta^{13} C / \ln f \text { and } b_{\mathrm{H}}=\delta^{2} H / \ln f .
$$

Fractionation factors $\alpha_{\mathrm{C}}$ and $\alpha_{\mathrm{H}}$ were calculated as $\alpha=1,000 /(b+1,000)$, and also expressed as isotope enrichment factors $\left(\varepsilon_{\mathrm{C}}\right.$ and $\left.\varepsilon_{\mathrm{H}}\right)$, calculated as $\varepsilon=(\alpha-1) 10^{3}$. Errors represent $95 \%$ confidence intervals calculated on the least-squares regression.

\section{RESULTS}

Several chloromethane-degrading bacteria with the $\mathrm{cmu}$ pathway have been characterized (Schäfer et al., 2007), and a complete and assembled genome sequence is available for two of them, i.e., $M$. extorquens CM4 (Marx et al., 2012) and Hyphomicrobium sp. MC1 (Vuilleumier et al., 2011). Two types of organization of $\mathrm{cmu}$ genes were identified (Nadalig et al., 2011). The usual gene organization involves a putative cmuBCA operon and was found in all 


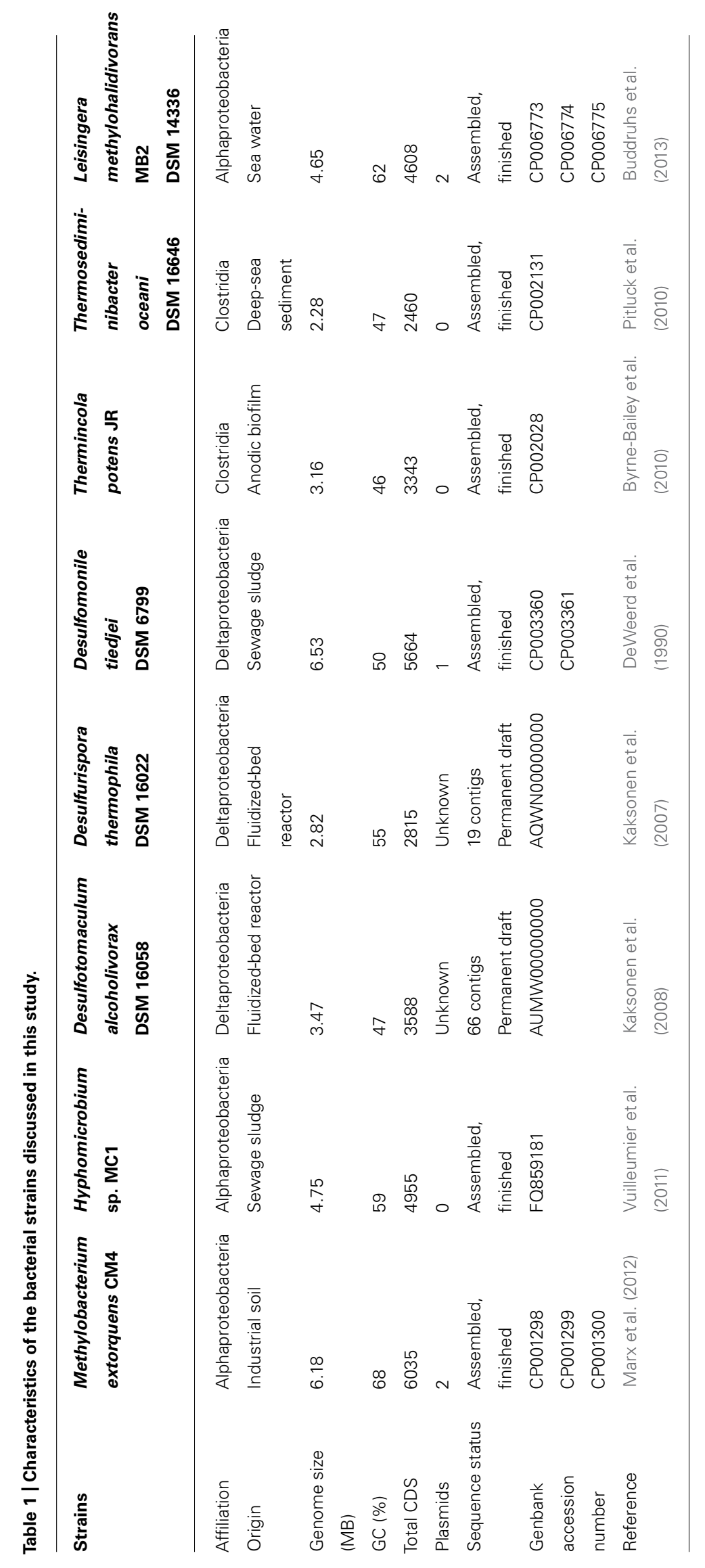




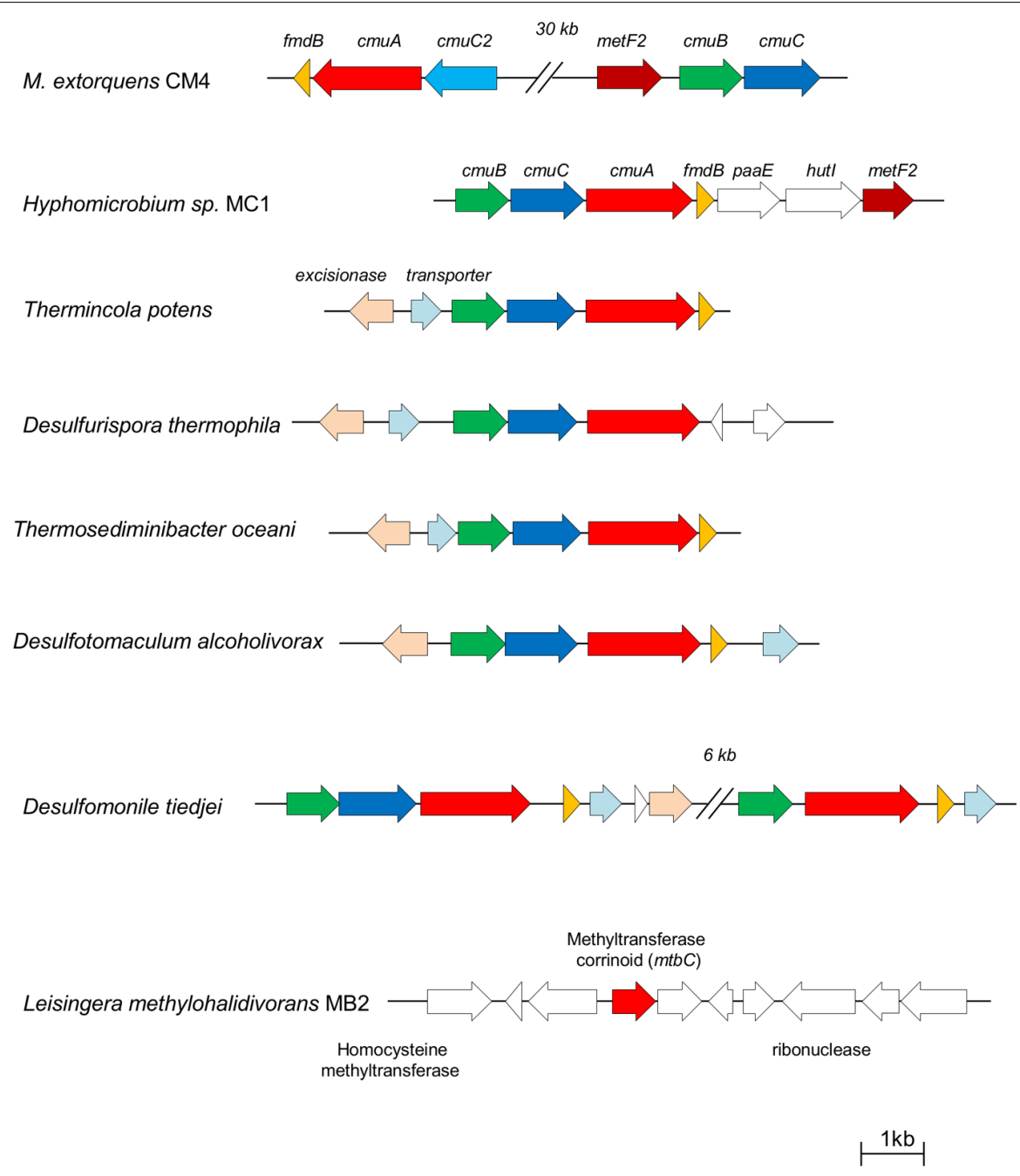

FIGURE 1 | Comparison of $\mathbf{c m u}$ gene organization in sequenced genomes of chloromethane-degrading bacteria. Arrows represent protein-coding genes, and homologous genes are shown in the same color. Gene clusters are drawn to scale.

experimentally characterized chloromethane-degrading bacteria with the $c m u$ pathway except the reference chloromethanedegrading strain $M$. extorquens CM4, which harbors $c m u$ genes in two clusters (Figure 1). The chloromethane-degrading strain $L$. methylohalidivorans MB2, in contrast, was known to lack $\mathrm{cmu}$ genes (Schäfer et al., 2007), so the recent report of its assembled genome sequence (Buddruhs et al., 2013) was of particular interest.

\section{COMPARATIVE GENOMICS}

An exhaustive survey of the presence of $\mathrm{cmu}$ genes in available sequenced bacterial genomes was carried out, yielding several novel insights (Table 2). First, all strains with $c m u$ homologs contained all three genes $c m u A, c m u B$, and $c m u C$ essential for growth with $\mathrm{CH}_{3} \mathrm{Cl}$ using the $c m u$ pathway. Second, these three genes were detected as a $c m u B C A$ gene cluster (Figure 1) in the genomes of five bacterial strains that had not been reported to possess $\mathrm{cmu}$ genes or $\mathrm{CH}_{3} \mathrm{Cl}$ degradation activity. Strikingly and in contrast to all strains growing with
$\mathrm{CH}_{3} \mathrm{Cl}$ using the $\mathrm{cmu}$ pathway described so far, all these strains are anaerobes. Three of them are Gram-negative bacteria from the class Deltaproteobacteria, i.e., Desulfotomaculum alcoholivo$\operatorname{rax}$ (Kaksonen et al., 2008), Desulfurispora thermophila (Kaksonen et al., 2007) and Desulfomonile tiedjei (DeWeerd et al., 1990), and two belong to the class Clostridia, i.e., the Gram-positive Thermincola potens (Byrne-Bailey et al., 2010) and the Gram-negative Thermosediminibacter oceani (Pitluck et al., 2010). Notably, Desulfomonile tiedjei has a second $c m u$ cluster containing only $c m u B$ and стиA (Figure 1) $6 \mathrm{~kb}$ away from a cmuBCA gene cluster. Levels of identity with homologs of the CM4 strain at the protein level are high, and range between 64 and 84\%, 60 and $64 \%$, and 34 and 39\% for $c m u A, c m u B$ and $c m u C$ gene products, respectively (Table 2). Pairwise identity comparisons of the proteins encoded by $\mathrm{cmu}$ genes show that homologs of strains Desulfotomaculum alcoholivorax, Desulfurispora thermophila, Thermincola potens and Thermosediminibacter oceani are most related to each other, with identities at the protein level between $84-93 \%$, 82-92\%, and 66-87\% for $c m u A, c m u B$, and $c m u C$ gene products, respectively, and that 


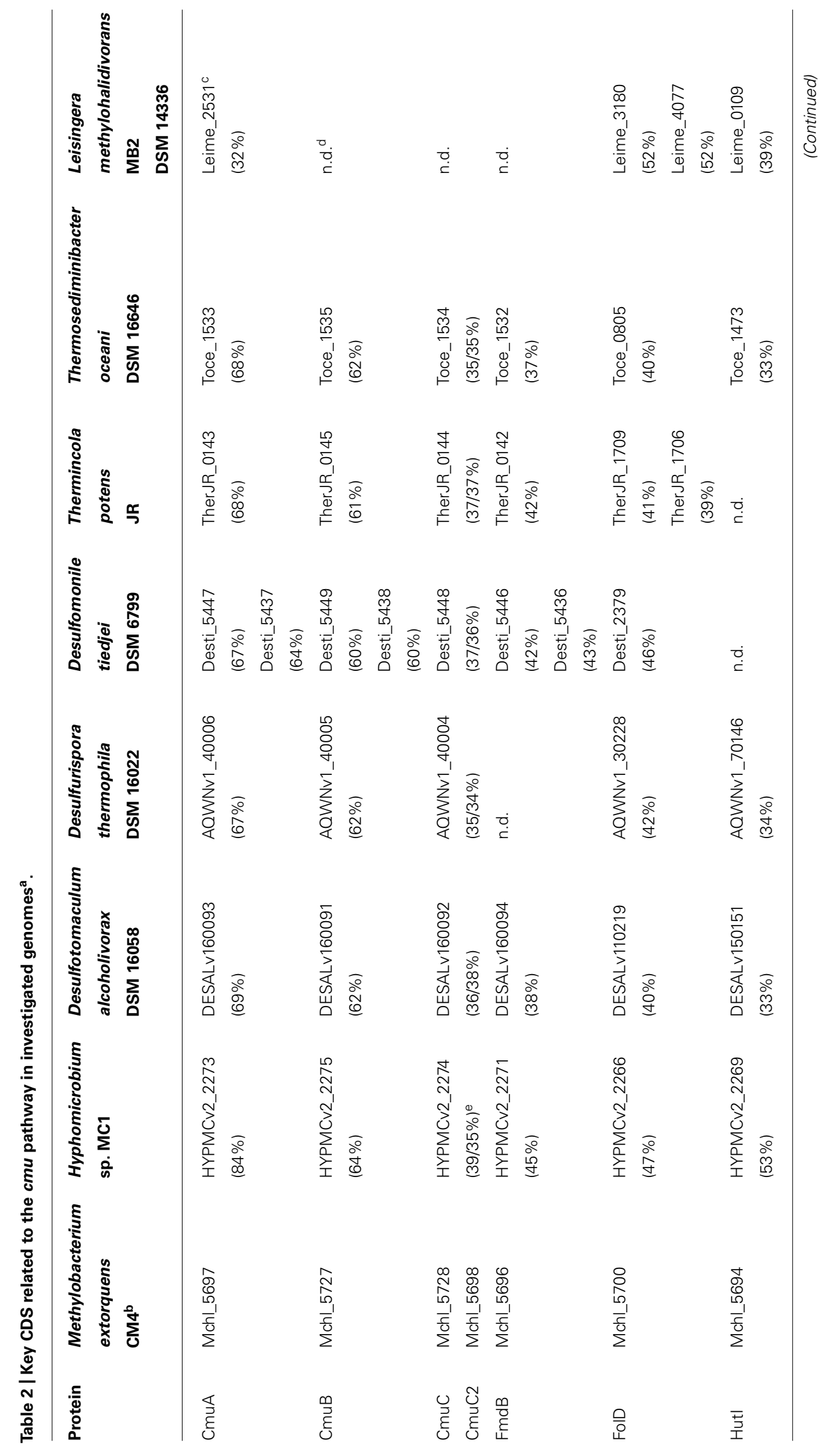




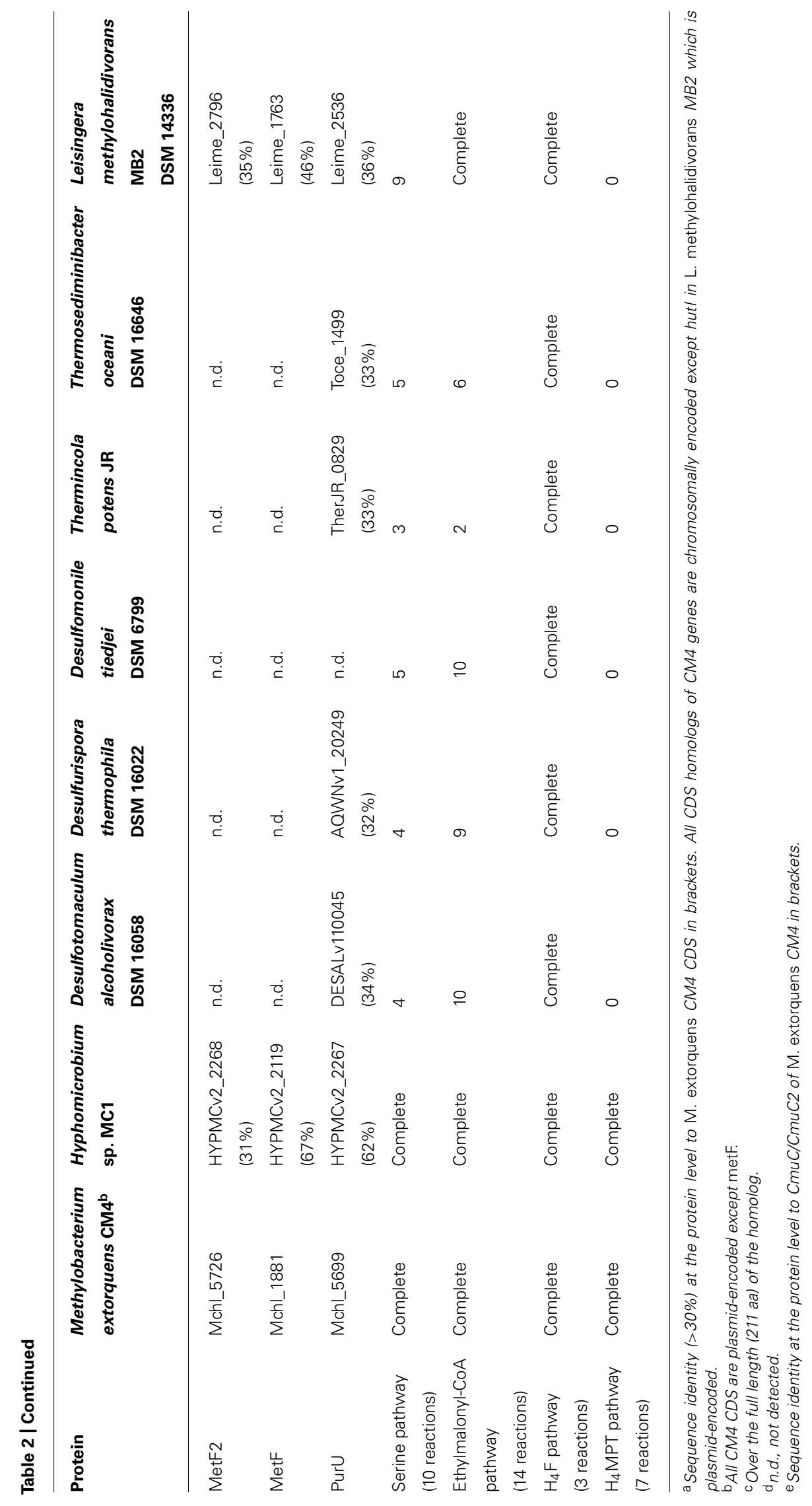


CM4 homologs represent outliers for all three genes. It is interesting to note that the gene products of two copies of $\mathrm{cmuA}$ and $c m u B$ of Desulfomonile tiedjei (78 and $77 \%$ protein identity, respectively) are not each others' closest homologs. In addition, no evidence for substantial identity at the DNA level was detected between the two $\mathrm{cmu}$ gene clusters of this strain (data not shown). Further, CmuA encoded by the cmuBCA cluster of Desulfomonile tiedjei is closer to homologs from other strains ( $>80 \%$ identity at the protein level) than that encoded by the partial $\mathrm{cmu}$ cluster cmuBA (<75\% identity).

Analysis of the L. methylohalidivorans MB2 genome (Buddruhs et al., 2013) confirmed the original report of Schäfer et al. (2007) that this $\mathrm{CH}_{3} \mathrm{Cl}$ strain did not contain bona fide cmu genes. As mentioned in the genome report, the closest homolog to $\mathrm{cmuA}$ is a gene coding a short (232 residues) corrinoid methyltransferase protein (MtbC) with only $32 \%$ identity to the $C$-terminal domain of CmuA (Table 2). However, no full-length homologs to $\mathrm{cmuB}$ and $\mathrm{cmuC}$ were detected in the genome sequence (Table 2). Taken together, these data confirm that the metabolic pathway used by $L$. methylohalidivorans $\mathrm{MB} 2$ to grow with $\mathrm{CH}_{3} \mathrm{Cl}$ is different to that of other known chloromethane-degrading strains with the $\mathrm{cmu}$ pathway.

The presence of downstream genes in the $c m u$ pathway in strains containing cmuABC genes was also evaluated (Table 2). Genes potentially involved in the tetrahydrofolate $\left(\mathrm{H}_{4} \mathrm{~F}\right)$ dependent pathway for oxidation of methyl- $\mathrm{H}_{4} \mathrm{~F}$ to formate via methylene- $\mathrm{H}_{4} \mathrm{~F}$ are present in all genomes (Table 2), but close homologs of met $\mathrm{F}$ encoding methylene- $\mathrm{H}_{4} \mathrm{~F}$ reductase were not detected except in strain MC1. Notably, only Alphaproteobacterial strains CM4, MC1, and L. methylohalidivorans MB2 possess the genes involved in the serine and ethylmalonyl-CoA pathways involved in growth of strains CM4 and MC1 with $\mathrm{C1}$ compounds. Moreover, the tetrahydromethanopterin $\left(\mathrm{H}_{4} \mathrm{MPT}\right)$ pathway crucial for growth of Methylobacterium with methanol (Marx et al., 2005), but thought to be dispensable for growth with $\mathrm{CH}_{3} \mathrm{Cl}$ (Studer et al., 2002), is only present in M. extorquens CM4 and Hyphomicrobium sp. MC1 which also grow with methanol, but absent in L. methylohalidivorans MB2, which is unable to grow with methanol, as well as in all other strains containing cmu genes investigated here. Finally, a search for genes common to chloromethane-degrading strains (including or excluding L. methylohalidivorans MB2) failed to reveal genes other than essential housekeeping genes (data not shown). This suggests that identification of the genes involved in $\mathrm{CH}_{3} \mathrm{Cl}$ degradation or in adaptation to $\mathrm{CH}_{3} \mathrm{Cl}$ metabolism is not possible by comparative genomics analysis alone.

\section{GROWTH OF STRAINS WITH CHLOROMETHANE AS SOLE CARBON AND ENERGY SOURCE}

Methylobacterium extorquens CM4, Hyphomicrobium sp. MC1, and L. methylohalidivorans MB2 were cultivated with $10 \mathrm{mM}$ $\mathrm{CH}_{3} \mathrm{Cl}$ as sole carbon and energy source in the recommended medium allowing fastest growth, i.e., minimal mineral medium for strains CM4 and MC1, and high-salt mineral medium for strain MB2 (Figure 2A). Chloromethane consumption during growth was measured in the gaseous phase by gas chromatography (Figure 2B). In cultures of $M$. extorquens CM4 and $H$.
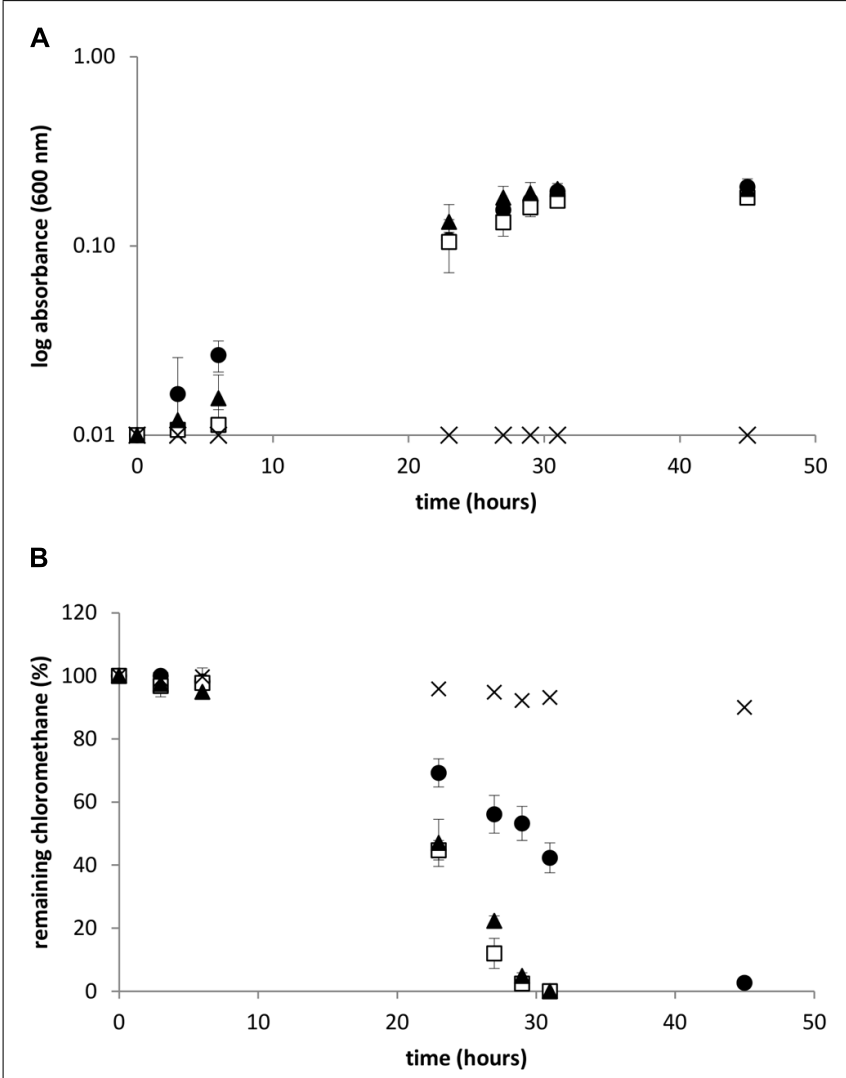

FIGURE 2 | Growth and chloromethane degradation during bacterial cultivation. Absorbance at $600 \mathrm{~nm}$ (A) and consumption of chloromethane (B). Leisingera methylohalidivorans $\operatorname{MB} 2(\bullet), M$. extorquens $\mathrm{CM} 4(\square)$ Hyphomicrobium sp. MC1 ( $\mathbf{\Delta})$ and abiotic control $(x)$. Error bars indicate the standard deviation of the mean of three biological replicates. Chloride concentration at the end of cultivation were $9.2 \pm 0.2$ and $9.2 \pm 0.3 \mathrm{~mol}$ $\mathrm{L}^{-1}$ for strains $\mathrm{CM} 4$ and $\mathrm{MC} 1$, respectively, but could not be measured in the high-salt medium used for growth of strains MB2.

sp. $\mathrm{MC1}, \mathrm{CH}_{3} \mathrm{Cl}$ was completely degraded after $30 \mathrm{~h}$ under the chosen growth conditions. In contrast, consumption of $\mathrm{CH}_{3} \mathrm{Cl}$ by the L. methylohalidivorans MB2 culture required a longer time $(\sim 45 \mathrm{~h})$ to proceed to completion, although its growth behavior was similar to that of the other two strains.

\section{CARBON AND HYDROGEN ISOTOPE FRACTIONATION OF CHLOROMETHANE DURING GROWTH}

During degradation of $\mathrm{CH}_{3} \mathrm{Cl}, \quad \delta^{13} \mathrm{C}$ values of residual chloromethane increased from approximately $-32 \%$ (initial value) to 55,9 , and $33 \%$ for strains $\mathrm{CM} 4, \mathrm{MC} 1$, and $\mathrm{MB} 2$ respectively (Figure 3A). No carbon or hydrogen fractionation was observed in abiotic controls with media M3 and MAMS (data not shown). Derived values of isotope fractionation factor $\left(\alpha_{C}\right)$ and of the corresponding enrichment factor were very similar for cmu pathway strains CM4 and $\mathrm{MC1}$, and substantially larger for L. methylohalidivorans MB2 (Table 3).

However, trends were markedly different for the three strains when considering the enrichment of ${ }^{2} \mathrm{H}$ in residual $\mathrm{CH}_{3} \mathrm{Cl}$ during cultivation. For strains $\mathrm{CM} 4$ and $\mathrm{MC} 1, \delta^{2} \mathrm{H}$ values increased 


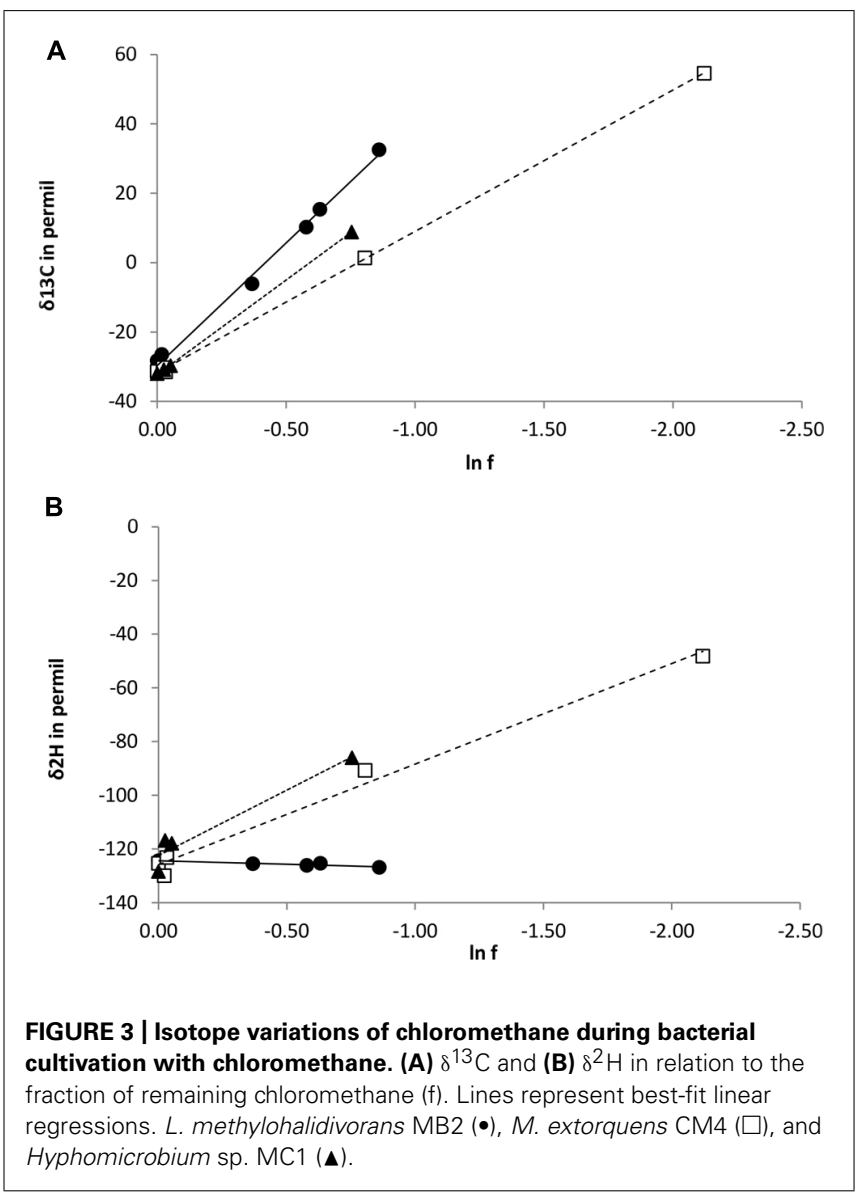

from approximately $-124 \%$ at the start of the experiment to $16 \%$ and $-12 \%$ for strains CM4 and MC1, respectively (Figure 3B). In marked contrast, however, no substantial change of $\delta^{2} \mathrm{H}$ was observed during degradation of $\mathrm{CH}_{3} \mathrm{Cl}$ by $L$. methylohalidivorans MB2 (Figure 3B). This resulted in large differences of hydrogen stable isotope fractionation factor $\left(\alpha_{\mathrm{H}}\right)$ and of the corresponding enrichment factor between strains $\mathrm{CM} 4$ and MC1 containing the $\mathrm{cmu}$ pathway for $\mathrm{CH}_{3} \mathrm{Cl}$ degradation on the one hand, and strain MB2 lacking the corresponding genes on the other hand (Table 3).

\section{DISCUSSION}

The presence of $\mathrm{cmu}$ genes in recently completed genome sequences was somewhat expected, but their detection in exclusively anaerobic bacteria came as a surprise considering that they had so far only been found in aerobic chloromethanedegrading bacteria. Anaerobic chloromethane-degrading bacteria reported so far use a different, although in one case at least also corrinoid-dependent, pathway (Traunecker et al., 1991; Messmer et al., 1993; Freedman etal., 2004). Worthy of note, $\mathrm{CH}_{3} \mathrm{Cl}$ dehalogenation by the $\mathrm{cmu}$ pathway does not require aerobic conditions and is actually sensitive to oxygen (Studer et al., 2001). It is thus possible that anaerobic bacteria with $\mathrm{cmu}$ genes identified here (Table 2) are actually able to use $\mathrm{CH}_{3} \mathrm{Cl}$ as a carbon and energy source, although this remains to be tested experimentally.

The conserved $c m u B C A$ gene organization (Figure 1) in $\mathrm{CH}_{3} \mathrm{Cl}$-degrading bacteria (Nadalig etal., 2011), and the high level of identity between the protein sequences encoded by $\mathrm{cmu}$ genes of Thermincola potens, Desulfurispora thermophila, Thermosediminibacter oceani, Desulfotomaculum alcoholivorax, and Desulfomonile tiejdei (>81, >74, and $>58 \%$ for $c m u A, c m u B$, and $\mathrm{cmuC}$, respectively), suggests a common evolutionary origin for these genes and their dissemination in the environment by horizontal gene transfer. The presence of an excisionase in the immediate environment of cmu genes in these five strains (Figure 1) further supports acquisition of cmu genes by horizontal transfer in these strains, as does the presence of two cmu gene clusters in Desulfomonile tiedjei whose sequences are not closer related to each other than to those of other chloromethane-degrading strains. To our knowledge, however, potential sources of $\mathrm{CH}_{3} \mathrm{Cl}$ that would support dissemination of $\mathrm{cmu}$ genes in anaerobic environments have not yet been reported.

Incidentally, our analysis also confirms the particular status in the $\mathrm{cmu}$ pathway of $\mathrm{cmuC}$, a gene shown to be essential for growth of strain CM4 with $\mathrm{CH}_{3} \mathrm{Cl}$ (Studer et al., 2002; Roselli et al., 2013) but whose function remains elusive. Indeed, sequence conservation among the proteins encoded by genes $c m u A, c m u B$, and $c m u C$ are lowest for the $\mathrm{CmuC}$ gene product (Table 2). Moreover, the probable loss of a $\mathrm{cmuC}$ homolog in one of the two $\mathrm{cmu}$ gene clusters of Desulfomonile tiedjei strain CM4 (Figure 1) also hints at its possibly lesser role in $\mathrm{CH}_{3} \mathrm{Cl}$ metabolism.

As to the chloromethane-degrading strain L. methylohalidivorans MB2, analysis of its genome (Buddruhs et al., 2013) confirms the initial report (Schäfer et al., 2007) that it lacks the $c m u$ pathway. The best partial hit to CmuA (32\% amino acid identity) is a 211-residue corrinoid protein, and $\mathrm{cmuB}$ or $\mathrm{cmuC}$ homologs were not detected in the L. methylohalidivorans MB2 genome (Table 2). However, downstream genes of the $\mathrm{H}_{4} \mathrm{~F}$-dependent $\mathrm{cmu}$ pathway ( $m e t F$, folD, pur $U$ ) were all found, so an $\mathrm{H}_{4} \mathrm{~F}$-dependent metabolic

Table 3 | Isotopic enrichment $(\varepsilon)$ and fractionation $(\alpha)$ factors for carbon and hydrogen during growth with chloromethane.

\begin{tabular}{|c|c|c|c|c|c|c|}
\hline & $\varepsilon_{\mathrm{c}}(\% \mathrm{o})$ & $R^{2 a}$ & $\alpha_{c}$ & $\varepsilon_{\mathrm{H}}(\%)$ & $R^{2 a}$ & $\alpha_{\mathbf{H}}$ \\
\hline Methylobacterium extorquens CM4 & 42 & 0.9997 & 1.042 & 39 & 0.9886 & 1.039 \\
\hline Hyphomicrobium sp. MC1 & 54 & 0.9999 & 1.054 & 51 & 0.9418 & 1.051 \\
\hline Leisingera methylohalidivorans MB2 & 76 & 0.9951 & 1.076 & 0 & 0.8230 & 1.000 \\
\hline
\end{tabular}

a Quality of fit to linear least-squares regression. 
pathway for growth of $L$. methylohalidivorans $\mathrm{MB} 2$ with $\mathrm{CH}_{3} \mathrm{Cl}$ remains a possibility.

In our experiments, we showed that L. methylohalidivorans MB2, previously grown with $\mathrm{CH}_{3} \mathrm{Cl}(0.37 \mathrm{mM}$; Schaefer et al., 2002), is capable of using this one-carbon compound as sole carbon and energy source at an initial concentration of $10 \mathrm{mM}$. A direct comparison of its growth behavior with that of strains CM4 and MC1 is prevented by the fact that the latter two strains do not grow in high-salt mineral medium, whereas L. methylohalidivorans MB2 does not grow in the standard low-salt mineral medium used for strains CM4 and MC1. Incidentally, this suggests that salt adaptation may be unrelated to adaptation to intracellular chloride production during dehalogenation, as observed recently for bacteria growing with dichloromethane (Michener et al., 2014).

The differences in $\mathrm{CH}_{3} \mathrm{Cl}$ metabolism of L. methylohalidivorans $\mathrm{MB} 2$ suggested by comparative genomics were experimentally supported by isotope analysis (Figure 3; Table 3). For $L$. methylohalidivorans $\mathrm{MB} 2$, isotopic enrichment factor for carbon during growth was substantially larger than for CM4 and $\mathrm{MC}$, indicating a larger primary isotope effect and providing further evidence for operation of another pathway for utilization of $\mathrm{CH}_{3} \mathrm{Cl}$ in this strain. In contrast, a previous study on carbon isotopic fractionation of $\mathrm{CH}_{3} \mathrm{Cl}$ by cell suspensions of three bacterial strains, including L. methylohalidivorans MB2, gave similar isotopic enrichment values (ranging between 42 and 47\%o; Miller et al., 2001). In particular, the value obtained for Aminobacter ciceronei strain IMB1, the only strain so far shown to possess cmuA but not $c m u B$ (Woodall et al., 2001), was similar to those of strains CM4 and MC1 (Miller etal., 2001). This suggests that the corrinoid dehalogenase protein CmuA drives carbon isotopic fractionation in chloromethanedegrading strains with the $c m u$ pathway. Moreover and unlike for carbon, a larger isotope effect than in previous resting cell experiments (Nadalig et al., 2013) was observed for hydrogen during growth in strains CM4 and MC1. However, the most striking finding of the present study was the lack of substantial hydrogen isotope enrichment upon $\mathrm{CH}_{3} \mathrm{Cl}$ degradation by L. methylohalidivorans MB2. This suggests that unlike CmuAB chloromethane dehalogenase, the unknown dehalogenase of this strain does not cause hydrogen fractionation during degradation of the chloromethane methyl group. Nevertheless and as a common denominator to all three chloromethane-degrading strains investigated here (Table 3), carbon isotope fractionation (the primary isotope effect in cleavage of the carbon-halogen bond) was more pronounced than hydrogen isotope fractionation (a secondary isotope effect in $\mathrm{CH}_{3} \mathrm{Cl}$ dehalogenation), as expected (Elsner et al., 2005).

The observed differences in isotopic fractionation of $\mathrm{CH}_{3} \mathrm{Cl}$ carbon and hydrogen between the three strains $\mathrm{CM} 4, \mathrm{MC1}$, and MB2 are best visualized in Figure 4, which shows the trends in enrichment of the heavier isotope of carbon and hydrogen for the different strains at different time points during growth. As proposed by Elsner et al. (2005), the slopes in these graphs constitute a clear indication that L. methylohalidivorans MB2 uses a different pathway for growth with $\mathrm{CH}_{3} \mathrm{Cl}$ than strains $\mathrm{CM} 4$ and $\mathrm{MC1}$, which utilize the same pathway.

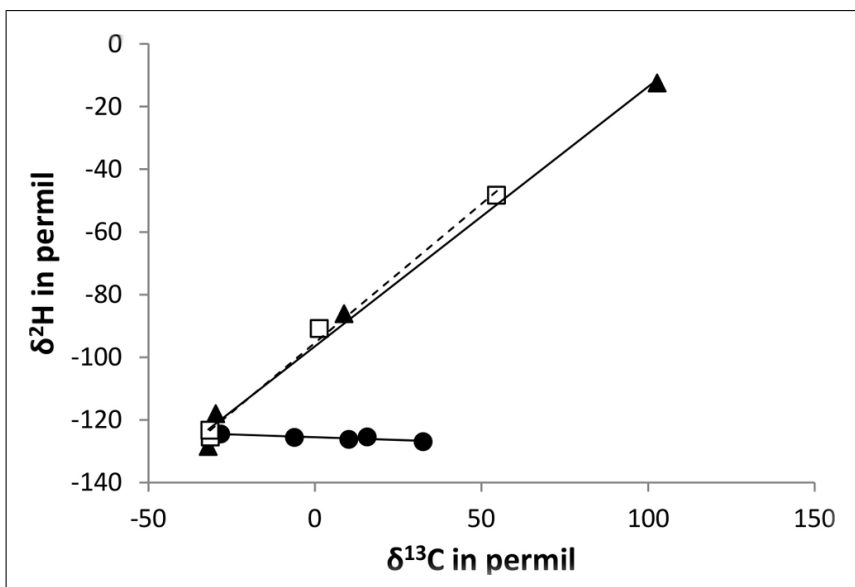

FIGURE 4 | Changes in carbon and hydrogen isotope ratios for degradation of chloromethane by $L$. methylohalidivorans MB2 ( $\bullet), M$. extorquens CM4 ( $\square$ ), and Hyphomicrobium sp. MC1 (४) at different time points during growth (increase in time from left to right of the graph). Lines (slope $=-0.03\left(R^{2}: 0.8014\right)$ for strain MB2, slope $=0.89$ $\left(R^{2}: 0.9954\right)$ for strain $\mathrm{CM} 4$, and slope $=0.83\left(R^{2}: 0.9939\right)$ for strain $\mathrm{MC1}$, respectively) represent best fit regressions.

Measurements of isotopic fractionation for a given environmental compartment will include the overall contribution of the metabolic diversity of chloromethane-degrading bacteria and their relative occurrence in that environment. It is tempting to speculate that chloromethane degradation in the soil environment, for which an isotopic fractionation of $49 \%$ similar to that found here for strains CM4 and MC1 was obtained in a previous study (Miller et al., 2004), is predominantly performed by bacteria with the cmu pathway. Our results on microbially driven hydrogen and carbon isotope fractionation suggest that using in a two-dimensional isotope scheme might help to confirm this hypothesis. Thus, a combination of genomic studies with physiological and isotopic characterisation of chloromethane-degrading bacterial strains, as performed here, will remain a major objective for the near future in order to constrain the bacterial sink strength of the atmospheric budget of $\mathrm{CH}_{3} \mathrm{Cl}$.

\section{ACKNOWLEDGMENTS}

Financial support for the acquisition of GC-FID equipment from REALISE (http://realise.unistra.fr), the Alsace network for research and engineering in the environmental sciences, is gratefully acknowledged. Frank Keppler is supported by the ESF (EURYI Award to Frank Keppler) and DFG (KE 884/2-1), and by the DFG research unit 763 "Natural Halogenation Processes in the Environment - Atmosphere and Soil” (KE 884/6-1; KE 884/7-1).

\section{REFERENCES}

Buddruhs, N., Chertkov, O., Petersen, J., Fiebig, A., Chen, A., Pati, A., et al. (2013). Complete genome sequence of the marine methyl-halide oxidizing Leisingera methylohalidivorans type strain (DSM 14336T), a member of the Roseobacter clade. Stand. Genomic Sci. 9, 128-141. doi: 10.4056/sigs.4297965

Byrne-Bailey, K. G., Wrighton, K. C., Melnyk, R. A., Agbo, P., Hazen, T. C., and Coates, J. D. (2010). Complete genome sequence of the electricityproducing "Thermincola potens" strain JR. J. Bacteriol. 192, 4078-4079. doi: 10.1128/JB.00044-10 
Coulter, C., Hamilton, J. T. G., McRoberts, W. C., Kulakov, L., Larkin, M. J., and Harper, D. B. (1999). Halomethane:bisulfide/halide ion methyltransferase, an unusual corrinoid enzyme of environmental significance isolated from an aerobic methylotroph using chloromethane as the sole carbon source. Appl. Environ. Microbiol. 65, 4301-4312.

Czapiewski, K., Czuba, E., Huang, L., Ernst, D., Norman, A., Koppmann, R., et al. (2002). Isotopic composition of non-methane hydrocarbons in emissions from biomass burning. J. Atmos. Chem. 43, 45-60. doi: 10.1023/A:1016105030624

DeWeerd, K. A., Mandelco, L., Tanner, R. S., Woese, C. R., and Suflita, J. M. (1990). Desulfomonile tiedjei gen. nov., and sp. nov., a novel anaerobic, dehalogenating, sulfate-reducing bacterium. Arch. Microbiol. 154, 23-30. doi: 10.1007/BF00249173

Doronina, N. V., Sokolov, A. P., and Trotsenko, Y. A. (1996). Isolation and initial characterization of aerobic chloromethane-utilizing bacteria. FEMS Microbiol. Lett. 142, 179-183. doi: 10.1111/j.1574-6968.1996.tb0 8427.x

Elsner, M., Zwank, L., Hunkeler, D., and Schwarzenbach, R. P. (2005). A new concept linking observable stable isotope fractionation to transformation pathways of organic pollutants. Environ. Sci. Technol. 39, 6896-6916. doi: 10.1021/es05 04587

Freedman, D., Swamy, M., Bell, N., and Verce, M. (2004). Biodegradation of chloromethane by Pseudomonas aeruginosa strain NB1 under nitratereducing and aerobic conditions. Appl. Environ. Microbiol. 70, 4629-4634. doi: 10.1128/AEM.70.8.4629-4634.2004

Greule, M., Huber, S. G., and Keppler, F. (2012). Stable hydrogen-isotope analysis of methyl chloride emitted from heated halophytic plants. Atmos. Environ. 62 584-582. doi: 10.1016/j.atmosenv.2012.09.007

Hamilton, J. T. G., McRoberts, W. C., Keppler, F., Kalin, R. M., and Harper D. B. (2003). Chloride methylation by plant pectin: an efficient environmentally significant process. Science 301, 206-209. doi: 10.1126/science.1 085036

Harper, D. B. (2000). The global chloromethane cycle: biosynthesis, biodegradation and metabolic role. Nat. Prod. Rep. 17, 337-348. doi: 10.1039/a809400d

Harper, D. B., Hamilton, J. T. G., Ducrocq, V., Kennedy, J. T., Downey, A., and Kalin, R. M. (2003). The distinctive isotopic signature of plantderived chloromethane: possible application in constraining the atmospheric chloromethane budget. Chemosphere 52, 433-436. doi: 10.1016/S0045-6535(03) 00206-6

Harper, D. B., Kalin, R. M., Hamilton, J. T. G., and Lamb, C. (2001). Carbon isotope ratios for chloromethane of biological origin: potential tool in determining biological emissions. Environ. Sci. Technol. 35, 3616-3619. doi: 10.1021/es0106467

Hartmans, S., Schmuckle, A., Cook, A. M., and Leisinger, T. (1986). Methyl chloride: naturally occurring toxicant and C-1 growth substrate. Microbiology 132, 11391142. doi: 10.1099/00221287-132-4-1139

Jörg, G., and Bertau, M. (2004). Thiol-tolerant assay for quantitative colorimetric determination of chloride released from whole-cell biodehalogenations. Anal. Biochem. 328, 22-28. doi: 10.1016/j.ab.2004.01.027

Kaksonen, A. H., Spring, S., Schumann, P., Kroppenstedt, R. M., and Puhakka, J. A. (2007). Desulfurispora thermophila gen. nov., sp. nov., a thermophilic, spore-forming sulfate-reducer isolated from a sulfidogenic fluidized-bed reactor. Int. J. Syst. Evol. Microbiol. 57, 1089-1094. doi: 10.1099/ijs.0.64 593-0

Kaksonen, A. H., Spring, S., Schumann, P., Kroppenstedt, R. M., and Puhakka, J. A (2008). Desulfotomaculum alcoholivorax sp. nov., a moderately thermophilic, spore-forming, sulfate-reducer isolated from a fluidized-bed reactor treating acidic metal- and sulfate-containing wastewater. Int. J. Syst. Evol. Microbiol. 58, 833-838. doi: 10.1099/ijs.0.65025-0

Keppler, F., Harper, D. B., Rockmann, T., Moore, R. M., and Hamilton, J. T. G. (2005). New insight into the atmospheric chloromethane budget gained using stable carbon isotope ratios. Atmos. Chem. Phys. 5, 2403-2411. doi: 10.5194/acp5-2403-2005

Keppler, F., Kalin, R., Harper, D., McRoberts, W. C., and Hamilton, J. T. G. (2004). Carbon isotope anomaly in the major plant $\mathrm{Cl}$ pool and its global biogeochemical implications. Biogeosciences 1, 393-412. doi: 10.5194/bgd-1-39 3-2004

Marx, C. J., Bringel, F., Chistoserdova, L., Moulin, L., Farhan Ul Haque, M., Fleischman, D. E., et al. (2012). Complete genome sequences of six strains of the genus Methylobacterium. J. Bacteriol. 194, 4746-4748. doi: 10.1128/JB.01 009-12

Marx, C. J., Van Dien, S. J., and Lidstrom, M. E. (2005). Flux analysis uncovers key role of functional redundancy in formaldehyde metabolism. PLoS Biol. 3:e16. doi: 10.1371/journal.pbio.0030016

McAnulla, C., McDonald, I. R., and Murrell, J. C. (2001). Methyl chloride utilising bacteria are ubiquitous in the natural environment. FEMS Microbiol. Lett. 201, 151-155. doi: 10.1111/j.1574-6968.2001.tb10749.x

Messmer, M., Wohlfarth., G., and Diekert, G. (1993). Methyl chloride metabolism of the strictly anaerobic, methyl chloride-utilizing homoacetogen strain MC. Arch. Microbiol. 160, 383-387. doi: 10.1007/BF00252225

Michener, J., Vuilleumier, S., Bringel, F., and Marx, C. J. (2014). Phylogeny poorly predicts the utility of a challenging horizontally-transferred gene in Methylobacterium strains. J. Bacteriol. 196, 2101-2107. doi: 10.1128/JB.00034-14

Miller, L., Connell, G., Guidetti, J., and Oremland, R. (1997). Bacterial oxidation of methyl bromide in fumigated agricultural soils. Appl. Environ. Microbiol. 63, 4346-4354.

Miller, L., Kalin, R. M., McCauley, S. E., Hamilton, J. T. G., Harper, D. B., Millet, D. B., et al. (2001). Large carbon isotope fractionation associated with oxidation of methyl halides by methylotrophic bacteria. Proc. Natl. Acad. Sci. U.S.A. 98, 5833-5837. doi: 10.1073/pnas.101129798

Miller, L., Warner, G., Baesman, S., Oremland, R., McDonald, I. R., Radajewski, S., et al. (2004). Degradation of methyl bromide and methyl chloride in soil microcosms: use of stable $\mathrm{C}$ isotope fractionation and stable isotope probing to identify reactions and the responsible microorganisms. Geochim. Cosmochim. Acta 68, 3271-3283. doi: 10.1016/j.gca.2003.11.028

Montzka, S. and Reimann, S. (2011). "Ozone-depleting substances (ODSs) and related chemicals," in Scientific Assessment of Ozone Depletion: 2010, Chap. 1, Global Ozone Research and Monitoring Project, Report No. 52. Geneva: World Meteorological Organization, 1-112.

Nadalig, T., Farhan Ul Haque, M., Roselli, S., Schaller, H., Bringel, F., and Vuilleumier, S. (2011). Detection and isolation of chloromethane-degrading bacteria from the Arabidopsis thaliana phyllosphere, and characterization of chloromethane utilization genes. FEMS Microbiol. Ecol. 77, 438-448. doi: 10.1111/j.1574-6941.2011.01125.x

Nadalig, T., Greule, M., Bringel, F., Vuilleumier, S., and Keppler, F. (2013). Hydrogen and carbon isotope fractionation during degradation of chloromethane by methylotrophic bacteria. Microbiologyopen 2, 893-900. doi: 10.1002/mbo3.124

Pitluck, S., Yasawong, M., and Munk, C. (2010). Complete genome sequence of Thermosediminibacter oceani type strain (JW/IW-1228PT). Stand. Genomic Sci. 3, 108-116. doi: 10.4056/sigs.1133078

Redeker, K. R., and Kalin, R. M. (2012). Methyl chloride isotopic signatures from Irish forest soils and a comparison between abiotic and biogenic methyl halide soil fluxes. Global Change Biol. 18, 1453-1467. doi: 10.1111/j.1365-2486.2011.02600.x Roselli, S., Nadalig, T., Vuilleumier, S., and Bringel, F. (2013). The $380 \mathrm{~kb}$ pCMU01 plasmid encodes chloromethane utilization genes and redundant genes for vitamin B12- and tetrahydrofolate-dependent chloromethane metabolism in Methylobacterium extorquens CM4: a proteomic and bioinformatics study. PLoS ONE 8:e56598. doi: 10.1371/journal.pone.0056598

Saito, T., and Yokouchi, Y. (2008). Stable carbon isotope ratio of methyl chloride emitted from glasshouse-grown tropical plants and its implication for the global methyl chloride budget. Geophys. Res. Lett. 35:L08807. doi: 10.1029/2007GL032736

Schaefer, J. K., Goodwin, K. D., McDonald, I. R., Murrell, J. C., and Oremland, R. S. (2002). Leisingera methylohalidivorans gen. nov., sp. nov., a marine methylotroph that grows on methyl bromide. Int. J. Syst. Evol. Microbiol. 52, 851-859. doi: 10.1099/ijs.0.01960-0

Schäfer, H., McDonald, I. R., Nightingale, P. D., and Murrell, J. C. (2005). Evidence for the presence of a CmuA methyltransferase pathway in novel marine methyl halide-oxidizing bacteria. Environ. Microbiol. 7, 839-852. doi: 10.1111/j.14622920.2005.00757.x

Schäfer, H., Miller, L. G., Oremland, R. S., and Murrell, J. C. (2007). Bacterial cycling of methyl halides. Adv. Appl. Microbiol. 61, 307-346. doi: 10.1016/S00652164(06)61009-5

Studer, A., McAnulla, C., Büchele, R., Leisinger, T., and Vuilleumier, S. (2002). Chloromethane induced genes define a third C1 utilization pathway in Methylobacterium chloromethanicum CM4. J. Bacteriol. 184, 3476-3482. doi: 10.1128/JB.184.13.3476-3484.2002 
Studer, A., Stupperich, E., Vuilleumier, S., and Leisinger, T. (2001). Chloromethane: tetrahydrofolate methyl transfer by two proteins from Methylobacterium chloromethanicum strain CM4. Eur. J. Biochem. 268, 2931-2938. doi: 10.1046/j.1432-1327.2001.02182.x

Traunecker, J., Preuss, A., and Diekert, G. (1991). Isolation and characterization of a methyl chloride utilizing, strictly anaerobic bacterium. Arch. Microbiol. 156, 416-421. doi: 10.1007/BF00248720

Vallenet, D., Engelen, S., Mornico, D., Cruveiller, S., Fleury, L., Lajus, A., et al. (2009). MicroScope: a platform for microbial genome annotation and comparative genomics. Database 2009, bap021. doi: 10.1093/database/bap021

Vannelli, T., Messmer, M., Studer, A., Vuilleumier, S., and Leisinger, T. (1999). A corrinoid-dependent catabolic pathway for growth of a Methylobacterium strain with chloromethane. Proc. Natl. Acad. Sci. U.S.A. 96, 4615-4620. doi: 10.1073/pnas.96.8.4615

Vuilleumier, S., Nadalig, T., Farhan Ul Haque, M., Magdelenat, G., Lajus, A., and Roselli, S., etal. (2011). Complete genome sequence of the chloromethane-degrading strain Hyphomicrobium sp. strain MC1. J. Bacteriol. 193, 5035-5036. doi: 10.1128/JB.05627-11

Woodall, C. A., Warner, K. L., Oremland, R. S., Murrell, J. C., and McDonald, I. R. (2001). Identification of methyl halide-utilizing genes in the methyl bromideutilizing bacterial strain IMB-1 suggests a high degree of conservation of methyl halide-specific genes in Gram-negative bacteria. Appl. Environ. Microbiol. 67, 1959-1963. doi: 10.1128/AEM.67.4.1959-1963.2001
Yoshida, Y., Wang, Y., Zeng, T., and Yantosca, R. (2004). A threedimensional global model study of atmospheric methyl chloride budget and distributions. J. Geophys. Res. 109:D24309. doi: 10.1029/2004JD 004951

Conflict of Interest Statement: The authors declare that the research was conducted in the absence of any commercial or financial relationships that could be construed as a potential conflict of interest.

Received: 29 July 2014; accepted: 19 September 2014; published online: 15 October 2014.

Citation: Nadalig T, Greule M, Bringel F, Keppler F and Vuilleumier S (2014) Probing the diversity of chloromethane-degrading bacteria by comparative genomics and isotopic fractionation. Front. Microbiol. 5:523. doi: 10.3389/fmicb.2014.00523

This article was submitted to Terrestrial Microbiology, a section of the journal Frontiers in Microbiology.

Copyright (c) 2014 Nadalig, Greule, Bringel, Keppler and Vuilleumier. This is an open-access article distributed under the terms of the Creative Commons Attribution License (CC BY). The use, distribution or reproduction in other forums is permitted, provided the original author(s) or licensor are credited and that the original publication in this journal is cited, in accordance with accepted academic practice. No use, distribution or reproduction is permitted which does not comply with these terms. 